\title{
GERAKAN POLITIK ISLAM VERSUS BELANDA
}

\author{
Maryam \\ Fakultas Ushuluddin, Adab dan Dakwah IAIN Bengkulu \\ Jalan Raden Fatah Pagar Dewa Bengkulu \\ maryam120216@gmail.com
}

\begin{abstract}
Islamic Political Movement Versus Dutch. Since the early seventeenth century the Indonesian nation entered into the period of colonization which was initiated by the Portuguese and the Spanish in order to organize a world tour, then came the nations in Asia. With the invention of a compass, a steam engine, and based on Copernicus's theory that the earth is round, then began the exploration of the world. Of the two nations, first emerged the ancient Imperalism. They have gold (gold-rich) gold, gospel, (religion as an effort to spread religion and continue the Crusade), and glory (meaning wealth to dominate the area). This has happened since the 15th and 16th centuries.
\end{abstract}

Keywords: Political Movement, Islam.

Abstrak: Gerakan Politik Islam Versus Belanda. Sejak awal abad ke 17 Bangsa Indonesia masuk kedalam masa penjajahan yang di awali oleh bangsa Portugis dan bangsa Spanyol dalam rangka mengadakan penjajahan keliling dunia, maka sampailah bangsa-bangsa tersebut di Asia. Dengan ditemukan kompas, mesin uap, dan berdasarkan teori Copernicus bahwa bumi ini bulat, maka dimulailah penjelajahan dunia. Dari kedua bangsa itu, pertama kali muncul adanya Imperalisme kuno. Mereka bersemboyan gold (emas lambing kekayaan), gospel, (agama sebagai usaha untuk penyebaran agama dan meneruskan Perang Salib), dan glory (kekayaan yang berarti ingin menguasai daerah-daerah yang didatanginya). Hal tersebut terjadi sejak abad ke-15 dan ke-16.

Kata Kunci: Gerakan Politik, Islam Belanda.

Pendahuluan

Sejak awal abad ke 17 Bangsa
Indonesia masuk kedalam masa
penjajahan yang di awali oleh bangsa
Portugis dan bangsa Spanyol dalam
rangka mengadakan penjajahan keliling
dunia, maka sampailah bangsa-bangsa
tersebut di Asia. Dengan ditemukan
kompas, mesin uap, dan berdasarkan teori
Copernicus bahwa bumi ini bulat, maka
dimulailah penjelajahan dunia. Dari kedua
bangsa itu, pertama kali muncul adanya
Imperalisme kuno. Mereka bersemboyan
gold (emas lambing kekayaan), gospel,
(agama sebagai usaha untuk penyebaran
agama dan meneruskan Perang Salib), dan
glory (kekayaan yang berarti ingin
menguasai daerah-daerah yang
didatanginya). Hal tersebut terjadi sejak
abad ke-15 dan ke-16.

$$
\text { Belanda menjajah Bangsa }
$$
Indonesia berlangsung kurang lebih selama 350 tahun, pada akhirnya menyadarkan bangsa Indonesia untuk keluar dari cengkraman tangan penjajah. Dalam pandangan kaum muslim pada waktu itu mengusir penjajah dari bumi pertiwi adalah kewajiban dan jihad $f i$ sabilillah. Untuk itu mulailah berdirinya lembaga organisasi yang menampung aspirasi kaum muslim dalam rangka mengusir para penjajah.

Sarekat Dagang Islam pada akhir berubah menjadi Sarekat Islam mengkonstrasikan diri pada bidang politik dan telah menorah sejarah bahwa basis pergerakan politik Islam cukup disegani oleh colonial. Menganggap S.1. Dalam tulisan ini penulis berusaha sedikit 
menguraikan tentang pergerakan politik Islam versus Kolonial.

Lahirnya Sarekat Dagang Islam (SDI) yang pada mulanya kebangunan pedagang Arab dan Sumatera yang merasa kedudukan mereka terancam karena kegiatan pedagang Cina (Diknas : 1978:39). Kejadian di daratan Cina telah mempengaruhi golongan orang Cina di Hindia Belanda untuk menuntut perbaikan dalam status sosial mereka. Pada permulaan colonial seperti penghapusan "Surat Past" (surat larangan) bagi orang Cina yang akan berpergian di luar daerah tempat tinggalnya biasanya mereka berdiam di suatu bagian kota. Konsesi ini diberikan karena perdagangan Belanda membutuhkan orang Cina sebagai pedagang perantara di desa-desa.

\section{POLITIK ISLAM MASA HINDIA BELANDA}

Penduduk Indonesia agamanya mayoritas muslim. Agama Islam secara terus menerus menyadarkan pemeluknya bahwa mereka harus membebaskan diri dari cengkeraman pemerintah kafir. Perlawanan dari raja-raja Islam terhadap pemerintah colonial bagai tak pernah henti. Padam di suatu tempat muncul di tempat lain. Belanda menyadari bahwa perlawanan itu diinspirasi oleh ajaran Islam (Badri Yatim : 2003:252).

Oleh karena itu agama Islam dipelajari secara ilmiah di negeri Belanda. Sering dengan itu, di sana juga diselenggarakan Indologie, ilmu untuk mengenal lebih jauh seluk beluk penduduk Indonesia. Semua itu dimaksudkan untuk mengukuhkan kekuasaan Belanda di Indonesia (Amir
Sutarga : 1987:31). Hasil dari pengkajian itu, lahirlah apa yang dikenal dnegan politik: Tokoh utama dan peletak dasarnya adalah Prof. Snouck Hurgronje. Dia berada di Indonesia antara tahun 1889 dan 1906. Berkat pengalamannya di Timur Tengah, Sarjana sastra Semit ini berhasil menemukan suatu pola dasar bagi kebijaksanaan menghadapi Islam di Indonesia, yang menjadi pedoman bagi pemerintah Hindia Belanda, terutama bagi Adviseur voor Inlandsche Zaken, lembaga penasihat gubernur Jenderal tentang segala sesuatu mengenai pribumi.

Ketika dibukanya Terusan Suez tahun 1869, setiap tahun ribuan umat Islam Indonesia pulang dari Mekkah sehabis menunaikan ibadah haji. Mereka datang dengan perlawanan umat Islam yang dimotori oleh para haji dan ulama, sehingga banyak kalangan Belanda yang berpendapat bahwa ibadah haji menyebabkan pribumi menjadi fanatik. Oleh karena itu, pemerintah mengeluarkan banyak peraturan untuk mempersulit kaum muslimin dalam menunaikan ibadah. Dalam hal ini, Snouck Hurgronje berusaha mendudukan masalah antara ibadah haji dan fanatisme. Menurutnya, haji-haji itu tidak berbahaya bagi kedudukan pemerintah kolonial di Indonesia. yang mungkin sekali berbahaya ialah apa yang dimaksud koloni Jawa, daerah tempat tinggal orang-orang yang berasal dari Indonesia di Mekkah. Karena pergaulan hidup bertahun-tahun, mereka telah menciptakan kesadaran yang lebih tinggi tentang persatuan kaum muslimin sedua. Disana mereka memperoleh bacaan-bacaan di tempattempat pendidikan agama, dan turut serta 
dalam kehidupan dan usaha-usaha PanIslam.

Berdasarkan pemahamnnay, Islam dapat dibagi menjdi dua bagian, yang satu Islam religious dan yang lain Islam politik. Terhadap masalah agama, pemerintah Belanda disarankan agar bersikap toleran yang dijabarkan di dalam sikap netral terhadap kehidupan keagamaan. Toleransi terhadapnya merupakan suatu syarat mutlak demi ketenangan dan stabilitas. Akan tetapi, Islam politik harus selalu dicurigai dan diteliti dari mana datangnya, terutama yang dipengaruhi gagasan Pan-Islam. Bahkan dalam analisanya itu, pemerintah diusulkan untuk meningkatkan pelayanan haji karena haji termasuk wilayah netral. Meskipun demikian, batas antara sikap netral dan campur tangan terhadap agama, bahkan antara membantu dan menghalagi, tidak begitu jelas. Pemerintah Belanda tetap saja banyak mengeluarkan berbagai peraturan untuk mengontrol secara ketat lembaga-lembaga pendidikan Islam.

Dalam rangka membendung pengaruh Islam, pemerintah Belanda mendirikan lembaga pendidikan bagi bangsa Indonesia, terutama untuk kalangan bangsawan. Mereka harus ditarik kearah westernisasi. Dalam pandangan Snouck Hurgronje, Indonesia harus melangkah kearah modern itu. Para lulusan sekolah ini diharapkan dapat menjadi partner dalam kehidupan sosial dan budaya Snouck Hurgronje memang mendambakan kesatuan Indonesia dan Belanda dalam suatu ikatan Pax Neerlandica. Oleh karena itu, dalam lembaga pendidikan Belanda tersebut, bangsa Indonesia harus dituntun untuk bisa berasosiasi dengan kebudayaan Belanda. Menurutnya, pendidikan Barat adalah alat yang paling pasti untuk mengurangi dan akhirnya mengalahkan pengaruh Islam di Indonesia.

Lulusan lembaga pendidikan Belanda itu, pada masa pergerakan, meski tidak seluruhnya, dikenal sebagai golongan nasionalis sekuler. Sekalipun mereka seringkali terlibat dalam persaingan dengan golongan Islam, kedua golongan itu, ternyata disatukan oleh rasa nasionalisme yang sama. Oleh karena itu mereka bahu membahu memperjuangkan kemerdekaan Indonesia dari penjajahan Belanda. Melalui lembaga pendidikan itu, ternyata gagasan Pax-Neerlandica tidak tercapai, bahkan justru lulusan-lulusannya menjadi orang-orang yang sangat gigih memperjuangkan kemerdekaan.

Analisa Snouck Hurgronje tentang potensi pribumi dan teorinya tentang pemisahan unsur agama dari unsur politik, tidak sejalan dengan perkembangan situasi, terutama dua puluh tahun terakhir kekuasaan Belanda di Indonesia. Oleh karena itu, peranan politik Kantor voor Inlandsche Zaken semakin menghilang pada tahun-tahun terakhir, meskipun wewenangnya mengawasi gerakan politik dipertegas sejak tahun terakhir, meskipun wewenangnya mengawasi gerakan politik lebih dipertegas sejak tahun 1931. Kantoor ini memang harus menjamin kelangsungan pemerintah Hindia Belanda.

\section{Sarekat Islam}

Syarikat Islam / Sarekat Islam (disingkat SI) dahulu bernama Sarekat Dagang Islam (disingkat SDI) didirikan 
oleh Haji Samanhudi pada tanggal 16 Oktober 1905, Sarekat Dagang Islam merupakan organisasi pertama yang lahir di Indonesia, pada awalnya Organisasi Sarekat Islam yang dibentuk oleh Haji Samanhudi ini merupakan perkumpulan pedagang-pedagang Islam yang menentang masuknya pedagang asing yang ingin menguasai ekonomi rakyat.

Pada tahun 1912 berkat keadaan politik dan sosial pada masa tersebut HOS Tjokroaminoto menggagas SDI untuk mengubah nama dan bermetamorfosis menjadi organisasi pergerakan yang hingga sekarang disebut Syarikat Islam, Hos Tjokroaminoto mengubah yuridiksi SDI lebih luas yang dulunya hanya mencakupi permasalahan sosial dan ekonomi. kearah politik dan Agama untuk menyumbangkan semangat perjuangan islam dalam semangat juang rakyat terhadap kolonialisme dan imperialisme pada masa itu. .

Hal ini menunjukkan bahwa Sarekat Islam adalah suatu organisasi yang telah lama diinginkan oleh rakyat umum (juga diantara pedagang dan kalangan agama). Lain dari pada disebabkan oleh rasa kepedihan nasional umum (dijajah oleh bangsa asing yang memluk agama lain, hal yang menjadi lebih terasa berhubungan dengan kesadaran Asia seumumnya), di daerah kerajaan-kerajaan Jawa di tempat Sarekat Islam mulai tumbuh, juga disebabkan oleh beberapa hal yang khusus, yakni :

1. Perdagangan bangsa Tionghoa adalah suatu halangan buat perdagangan Indonesia (monopoli bahan-bahan batik) ditambah pula dengan tingkah laku sombong Tionghoa sesudah revolusi di Tiongkok.

2. Kemajuan gerak langkah penyebaran agama kristern dan juga ucapan yang menghina dalam perlemen Negara Belanda tentang tipisnya kepercayaan agama bangsa Indonesia.

3. Cara adat lama yang terus di daerah kerajaan-kerajaan Jawa, makin lama makin dirasakan sebagai penghinaan.

Kegiatan SDI yang telah berubah dari bidang ekonomi kea rah bidang politik itu, semakin sulit untuk bergerak di daerah Solo. Akhirnya, ruang gerak SDI terpaksa berpindah-pindah dari daerah satu daerah lain. Di antara daderah yang paling tepat dan mendapat sambutan dari tokoh masyarakat setempat adalah pada saat pergerakan SDI di daerah Surabaya. Dengan demikian, Surabayalah yang dapat diandalkan untuk pusat pergerakan SDI. Oleh karena itu, pada tahun 1915 di Surabaya didirikan "Central Serikat Islam" dengan ketua terpilih Haji Samanhoedi dan wakil ketua H.O.S. Cokroaminoto.

Sejak H.O.S Cokroaminoto dalam kegiatan pergerakan organisasi tersebut, maka tampak jelas pergerakan dalam bidang politik lebih diutamakan, dari pada kegiatan dalam bidang ekonomi. Dengan perubahan langkah dan gerak perjuangan itu, maka sebutan nama organisasi tidak lagi SDI, melainkan S.1 pertama tanggal 17-24 Juni 1916 di Bandung. H.O.S Cokroaminoto lebih menonjol lagi, karena terkenal dengan keberaniannya dalam berpidato dalam setiap pertemuan atau rapat besar. Antara lain mengatakan sebagai berikut :

“.....Kepada Hindia Belanda diminta pertanggungjawabannya terhadap rakyat, 
yakni : melindungi penduduk bumi putera dari perbuatan sewenangwenangnya"....bahwa gerakan Islam itu diperkuat untuk membina suatu barisan Islam dalam usaha pembentukan suatu bangsa" (Ruben Nalenan, 1974: 91)

Pada kesempatan lain Cokroaminoto berpidato dalam kongres Serikat Islam yang berjudul "Zulfbetuur" tahun 1916 di Bandung mengatakan :

“Tidak pantas lagi Hindia diperintah oleh Negara Belanda, bagaikan tuan tanah yang menguasai tanah-tanahnya. Tidak pada tempatnya menganggap Hindia sebagai seekor sapi perahan yang hanya diberi makan demi susunya. Tidaklah pantas untuk menganggap negeri ini di tempat kemana orang berdatangan hanya untuk memperoleh keuntungan, dan sekarang sudah tidak pada tempatnya lagi, bahwa penduduknya, terutama anak negerinya sendiri,t idak mempunyai hak turu bicara dalam soal-soal pemerintahan yang mengatur nasib mereka" (Badri Yatim : 2003 : 259)

Demikianlah S.1 memperjuangkan pemerintahan sendiri bagi kedudukan Indonesia, bebas dari pemerintahan Belanda, dan dengan menonjolnya Cokroaminoto, maka kepemimpinan Haji Samanhoedi tidak tampak, sehingga selama 5 (lima) tahun Haji Samangoedi telah berhasil meneruskan cita-cita SDI, tetapi sebagai penerus dalam bidang politik adlaah Cokroaminoto. Sebenarnya kepemimpinan Haji Samanhoedi itu, mulai kurang menonjol sejak tahun 1913, karena hampir segala persoalan organisasi diserahkan kepada Cokroaminoto. Oleh karena itu, Cokroaminoto dalam tahun ini juga diangkat sebagai ketua S1, namun dalam pembentukan Central Serikat
Islam (CSI) tahun 1915 Haji Saman Hoedi masih didudukan sebagai ketua dan Cokroaminoto sebagai wakil ketua. Hal ini tampaknya untuk menghargai Haji Samanhoedi, karena telah ikut merintis perjuangan SDI sejak tahun 1991 yang seterusnya karena telah ikut merintis perjuangan SDI sejak tahun 1911 yang seterusnya sampai SDi menjadi pergerakan nasional untuk mencapai citacita pembentukan suatu bangsa, seperti yang diucapkan Cokroaminoto tersebut.

\section{Sikap Belanda Terhadap S1}

Dari kepemimpinan Cokroaminoto dalam S1 yang tegas itu, maka pihak pemerintah Hindia-Belanda semakin curiga terhadap organisasi ini. Terlebih lagi setelah Cokroaminoto sebagai ketua S1 dan Abdul Muis sebagai Wakil ketuanya, maka gerakan S1 tampak lebih terbuka, yakni mengajukan mosi pada tanggal 25 November 1916, yang selanjutnya lebih terkenal dengan "Mosi Cokroaminoto"yang isinya sebagai berikut :

1. Perlu dibentuk parlemen yang anggota-anggotanya dipilih rakyat dengan hak penuh menentukan hukum (undang-undang)

2. Dibentuk suatu pemerintahan yang bertanggung jawab kepada parlemen.

Semua kegiatan COkroaminoto sebagai ketua S.1 dinilai oleh pemerintahan Hindia-Belanda sangat merugikan, sehingga dicurigai. Namun mengingat Gubernur Jenderal HindiaBelanda pada saat itu, tidak kejam, maka mosi Cokroaminoto dijadikan pertimbangan untuk kebijakan dalam membentuk semacam Dewan Rakyat (Volksraad) Gubernur Jenderal Van 
Limburg Stirum pada tanggal 18 Mei 1917 meresmikan pembentukan Volksraad, dimana S.1 mewakilkan Cokroaminoto dan Abdul Muis menjadi anggota (Sudiyo, 2002: 33).

Berbeda dengan Gubernur Jenderal sebelumnya, yaitu Van Heutsz dan Indeburg, yang selalu bersikap keras dan kejam dalam setiap langkahynya untuk menindak kaum pergerakan nasional. Sedangkan semasa Gubernur Jenderal dijabat oleh Van Limburg Strum tampak banyak toleransinya terhadap tuntutan dari pihak kaum pergerakan nasional. Oleh karena itu, apa saja yang telah dilakukan oleh Gubernur Jenderal sebelumnya, tidak menjadi suatu pegangan. Sebagai contoh tentang kecurigaannya terhadap Sarekat Islam, dimana S.1 akan mengarah kepada pembentukan suatu bangsa. Untuk hal ini pada saat Gubernur Jenderal sebelumnya yaitu Indenburg menanggapinya sangat keras dan menuduh S.1 akan menggunakan persatuan Islam untuk melawan pemerintah. Oleh karena itu, dengan secepatnya pemerintah berusaha memecah organisasi S.1 itu.

Cara yang dipergunakan oleh pemerintahan Hindia-Belanda untuk memecah organisasi Islam itu adalah dengan mengadakan penyusupan ke dalam organisasi tersebut. Beberapa orang Belanda yang berpaham sosial demokrasi didatangkan ke Hindia Belanda. Mereka itu antara lain HJEM Sneevliet, JA Branstoday HW Dekker, dan Rergsma. Diantara mereka ini yang paling terkenal adalah Sneevliet. Oleh karena itu, ia diberi tugas untuk memimpin infilstrasi (penyusupan) ke dalam tubuh organisasi Islam yang dianggap berbahaya itu.
Dengan kedok ikut memperbaiki nasib rakyat, maka Sneevliet dan kawan-kawan mudah bergaul dengan orang-orang Sarekat Islam. Melalui pergaulan inilah paham sosialis demokrasi dimasukkan. Bahkantidak sedikit ajaran marvis masuk ke dalam tubuh JJSI itu. Akibatnya banyak orang-orang SI yang tertarik dengan ajaran tersebut. Oleh karena itu, dalam jangka waktu yang tidak terlalu lama, yaitu sejak kedatangan orang-orang Belanda berpaham sosialis demokrasi pada tahun 1913 sehingga pada bulan Mei 1914 di Semarang didirikan Indische Social Demokratische Vereniging (ISDV). Banyak oran-orang S.1 masuk ke dalam ISDV dibentuk oleh orang-orang Belanda (Sneevliet dkk) itu, memang bertujuan pemerintah memecah belah organisasi yang memiliki anggota sangat besar itu.

Orang-orang S1 yang masuk ISDV, antara lain Semaun, Dharsono Alimin, Tan Malaka, dan lain-lain. Perbedaan pandangan antara orang-orang S1 yang terpengaruh paham sosialis demokrasi dengan tidak terpengaruh, tampak semakin tajam, yakni pada saat pembentukan Sarekat Buruh pada tahun 1919 Sarekat Buruh yang dibentuk itu bernama "Persatuan Pergerakan Kaum Buruh" (PPKB) dan langsung dibawah S1 yang berarti mempunyai garis hubungan vertikal kepada Central Sarekat Islam (CSI) Sarekat buruh ini juga dipimpin oleh Cokroaminoto Suryopranoto, Sosrokardono dan lain-lain. Sedangkan Semaum dkk dari ISDV menghendaki Sarekat Buruh dengan nama Revolutionair Socialistisiche vak Centrale. Dengan demikian Semaun memimpin dua organisasi buruh, yakni seperti tersebut di atas dan yang satu lagi bernama 
Vereniging van Spoor en Tramwegpersoneel (VSTP).

Memperhatikan permasalahan tersebut di atas, maka dalam tubuh S.1 ada perbedaan pandangan yang sangat mendasar. Yakni dalam hal paham (ideology) dan Sarekat Buruh. Oleh karena itu, dalam setiap selalu terjadi perdebatan yang tidak menghasilkan tidak temu. Salah satu pihak memandang dari segi Islam (kelompok Cokroaminoto dkk), dan di pihak lain memandang dari segi nonIslam, yaitu sosialis demokrasi yang berbau marxis. Dalam keadaan yang demikian, kelompok Cokroaminoto dan kawan-kawan mengusulkan kepada CSI, agar orang-orang yang memiliki keanggotaan rangkap diberikan suatu ketegasan untuk memilih masuk S.1 atau ISDV. Karena dua organisasi ini, mempunyai landasan dan tujuan yang berbeda. Dengan demikia, tidak dibenarkan memiliki keanggotaan rangkap.

Usulan Cokroaminoto dan kawankawan itu disetujui oleh CSI, sehingga pada tahun 1920, terjadi perpecahan dalam tubuh S.1. Satu pihak mengikuti kelompok Semaun dan kawan-kawan, yang menganut paham sosialis demokrasi berbau marxis dan yang satu pihak lagi mengikuti kelompok Cokroaminoto dan kawan-kawan yang tetap untuk meneruskan program lama, yaitu kebebasan ekonomi rakyat, berjiwa Islam, guna kekuatan dan persatuan. Selanjutnya kelompok Semaun dan kawan-kawan disebut S1 merah dan kelompok Cokroaminoto dan kawan-kawan disebut S1 putih.

Atas dorongan Semaun dan kawankawan, maka dalam kongres ISDV ke-7 tangga 23 Mei 1920, nama ISDV diubah menjadi "Perserekatan Komunis Hindia"dantidak lama kemudian pada tahun itu juga Perserekatan Komunis Hindia itu dirubah namanya menjadi "Perserekatan Komunis Indinesia (PKI)" Sedangkan S1putih dari kelompok Cokrominoto dan kawan-kawan menilai, bahwa Semaun dan kawan-kawan telah membelokkan haluan Islam dari S.1 ke haluan Komunis. Untuk menghadapi masalah tersebut, S.1 putih mengusulkan rapat kepada CSI untuk membahas pernyataan Sarekat Buruh. CSI menyetujui dan rapat diadakan pada bulan April 1923 dalam rapat tesebut diputuskan sebagai berikut :

$\checkmark$ Dibentuk organisasi Sarekat Buruh dengan nama "Persatuan Vakbond Hindia" (PVH)

$\checkmark$ Apabila ada seorang pemimpin buruh ditangkap, kaum buruh akan mengadakan pemogokan

Berhubung Semaun dan kawankawan, sangat memaksakan untuk pemogokan, sehingga kelompok Cokrominoto menyatakan ke luar dari $\mathrm{PVH}$ dan sekaligus juga mengubah sikapnya dari kooperatif ke non kooperatif. Dalam hal ini, berarti Sarekat Islam keluar dari Volksraad dan menanamkan organisasinya menjadi "Partai Sarekat Islam" (PSI) Meskipun demikian, sikap non kooperatif Psi teras kental sekali.

$\checkmark$ Dibentuk organisasi penyatuan Sarekat Buruh dengan nama "Persatuan Vakbond Hindia" (PVH) 
$\checkmark$ Apabila ada seorang pemimpin buruh ditangkap, kaum buruh akan mengadakan pemogokan

Berhubung Semaun dan kawan-kawan, sangat memaksakan untuk pemogokan sehingga kelompok Cokrominoto menyatakan ke luar dari PVH dan sekaligus juga mengubah sikapnya dari kooperatif ke non-kooperatif. Dalam hal ini, berarti Sarekat Islam keluar dari Volksraad dan menanamkan organisasinya menjadi "Partai Sarekat Islam" (PSI). Meskipun demikian, sikap non-kooperatif Psi terasa kental sekali.

\section{Kesimpulan}

Terjadinya perlawanan raja-raja sebelumnya penduduk Indonesia yang mayoritas beragama Islam, secara kontiyu menyadarkan pemeluknya untuk membebaskan diri dari penjajahan kafir yang menganggap mengusir penjajah jihad fi sabillah.

Melihat phenomena demikian Belanda melalui Prof Snouk Hurgronje telah mengetahui pola dasar bagi kebijakan Islam Indonesia. Perlawanan yang dimotori oleh para ulama membuat kolonial membuat kebijakan untuk mempersulit pelaksanaan ibadah haji, karena pihak kolonial mengetahui di Mekkah terdapat jaringan ulama yang terus memompa semangat patritisme haji Indonesia untuk mengusir penjajah, juga Belanda mendirikan sekolah untuk menarik bangsawan pribumi pada westernisasi.

Lahirnya Sarekat Dagang Islam yang kemudian berubah menjadi Sarekat Islam (S1) yang konsentarsi dalam pergerakan politik menjadi "momok" bagi colonial. Adapun diantara sebab lahirnya Sarekat Dagang Islam sebagai berikut :

1. Perdagangan bangsa Tionghoa adalah suatu halangan buat perdagangan Indonesia (monopoli bahan-bahan batik) ditambah pula dengan tingkah laku sombong bangsa Tionghoa sesudah revolusi di Tiongkok

2. Kemajuan gerak langkah penyebaran agama Kristen dan juga ucapanucapan yang menghina dalam parlemen Negara Belanda tentang tipisnya kepercayaan agama bangsa Indonesia

3. Cara adat lama yang terus dipakai di daerah kerajaan-kerajaan Jawa, makin lama makin diraswakan sebagai penghinaan.

Melihat gerakan S.1 di bawah komando H.O. Cokroaminoto mulai membahayakan Belanda, Belanda memecah tubuh S.1 dengan menyusupkan orang-orang Belanda di tubuh S. 1

\section{Referensi}

Pringdodigdo, Pergerakan Rakyat Indonesia, Dian Rakyat, Jakarta, 1991

Depdiknas, Sejarah Kebangkitan Nasional Daerah Jawa Barat, Bandung, 1978

Gayo, M.H. Perang Melawan Kolonalis

Belanda, Balai Pustaka, Jakarta, 1983

Indra, Ridwan dan Sopian Martadya, Peristiwa di sekitar Proklamasi, Sinar Grafika, Jakarta, 1989

Takashi Shiraishi, Zaman Bergerak Radikalisme Rakyat di tahun 1912-1926, Penerbit Pustaka Grafika Utama, Jakarta, 1990

Soekarno, Mencapai Indonesia Merdeka, PT. Suti Press, 1982.

Amir Sutarga, Politik Etis pra Revolusi Kemerdekaan, Yayasan Obor Indonesia, 1987

Yatim, Badri, Sejarah Peradaban Islam : Dirosah Islamiyah II, Raja Grafindo Persada, Jakarta, 2003

Zainul Ihsan, Tjokroaminoto, "Zelfbestru", Aku Pemuda Kemarin di hari Esok, Gunung Agung, Jakarta, 2003 